\title{
Pengaruh model Strength-based Counseling dalam LMS Schoology untuk meningkatkan kesehatan mental dan kesejahteraan psikologis siswa
}

\author{
Kadek Suranata $^{1}$, I Ketut Dharsana ${ }^{1}$, Wayan Eka Paramartha ${ }^{1}$, Kadek Ari Dwiarwati ${ }^{1}$, Ifdil Ifdil $\left.{ }^{2^{*}}\right)$ \\ ${ }^{1}$ Universitas Pendidikan Ganesha, Indonesia \\ ${ }^{2}$ Universitas Negeri Padang, Indonesia
}

\section{Article Info}

\section{Article history:}

Received Mar $27^{\text {th }}, 2021$

Revised Apr $10^{\text {th }}, 2021$

Accepted May $03^{\text {rd }}, 2021$

\section{Keyword:}

Strength-based counseling

Resilience

Well-being

Student's mental health

\begin{abstract}
Students' mental health is one of the central issues during the COVID-19 pandemic. Various studies have reported increasing psychological disorders experienced by students. An effort is needed to help students improve their mental health and psychological well-being. This study reports the effect of online strength-based counseling (SBC) model through LMS Schoology. The randomized control trial experiment design performed to examining the effect of intervention on this study to students well-being, resilience and Health life style. This study involved 465 students who were randomly assigned to the first experimental group assign the online SBC through LMS Schoology, the second experimental group assign to the SBC by the paper based module counseling guide, and the third is waiting list control. Manova and Anova statistic analysis used to test the hypothesis of this study. The results of this study show that online SBC through LMS Schoology is an effective intervention to help students improve healthy lifestyles and behaviors, resilience, and well-being. The findings in this study have implications for the implementation of guidance and counseling services in schools as an effort to improve students' mental health and psychological well-being.
\end{abstract}

(C) 2021 The Authors. Published by IICET

This is an open access article under the CC BY-NC-SA license

(https://creativecommons.org/licenses/by-nc-sa/4.0)

\section{Corresponding Author:}

Ifdil Ifdil,

Universitas Negeri Padang

Email: ifdil@konselor.org

\section{Pendahuluan}

Situasi pandemi COVID-19 telah berdampak luas pada berbagai dimensi kehidupan masyarakat. Tidak bisa dipungkiri, kondisi pandemi ini memacu masyarakat untuk dapat beradaptasi dengan cepat dengan beragam perubahan tatanan kehidupan dalam berbagai sektor, termasuk aktivitas pendidikan di sekolah. Beragam kebijakan telah diterapkan sebagai upaya menekan laju penyebaran virus. Di dunia pendidikan, adanya kebijakan pembatasan sosial berskala besar (PSBB) menyebabkan seluruh aktivitas pembelajaran dilaksanakan melalui mode daring.

Pemberlakuan berbagai kebijakan dalam bidang pendidikan menjadikan kesehatan mental dan kesejahteraan psikologis siswa menjadi salah satu isu penting yang perlu memerlukan perhatian. Hal ini dikarenakan rutinitas sekolah merupakan salah satu coping mechanism yang dimiliki oleh remaja (siswa), sehingga adanya perubahan aktivitas pembelajaran dari mode tatap muka menjadi mode daring menjadi salah satu faktor resiko munculnya gejala-gejala gangguan psikologis pada siswa (Lee, 2020). 
Beberapa studi telah melaporkan gangguan psikologis yang dialami siswa selama pandemi, seperti mengalami gangguan tidur, munculnya gangguan perilaku, dan meningkatnya resiko siswa mengalami stres (Ardan et al., 2020; Cornine, 2020; Singh et al., 2020; Thahir et al., 2020). Studi Li et al.,(2020)) melaporkan bahwa kondisi pandemi telah memicu munculnya peningkatan resiko siswa mengalami emosi negatif (kecemasan, depresi, kemarahan) serta memicu menurunnya tingkat life satisfaction.

Di Indonesia khusunya, aktivitas pembelajaran jarak jauh yang harus diikuti oleh siswa selama pandemi mengakibatkan siswa mengalami kecemasan cukup tinggi, karena sebagian besar siswa mengalami kesulitan dalam memahami materi, kesulitan dalam mengerjakan tugas-tugas, serta menghadapi beragam kendala teknis seperti keterbatasan kondisi jaringan internet. (Ardan et al., 2020; Oktawirawan, 2020). Tingkat kejenuhan belajar (academic burnout) yang dialami siswa juga dilaporkan mengalami peningkatan cukup tinggi (Rinawati \& Darisman, 2020).

Temuan-temuan tersebut mempertegas bahwa pada situasi pandemi ini, telah terjadi peningkatan ancaman resiko terhadap kesehatan mental siswa. Gangguan-gangguan psikologis yang dialami oleh siswa dapat berdampak terhadap penurunan performa akademik serta kesejahteraan psikologisnya (Puteh \& Khalin, 2016; Wahid et al., 2018). Oleh karena itu peran sekolah sebagai lembaga pendidikan yang bertujuan untuk membantu siswa mencapai perkembangan yang menyeluruh sangat diperlukan saat ini.

Upaya yang dapat dilakukan adalah melalui revitalisasi layanan psikoedukasi (WHO, 2020), salah satunya melalui layanan bimbingan dan konseling yang sebagaimana diamanatkan dalam Permendikbud nomer 111 tahun 2014 berperan penting dalam mengupayakan agar siswa dapat mengembangkan aspek-aspek psikologis secara optimal serta mampu menghadapi berbagai dinamika dalam kehidupannya. Pelayanan bimbingan dan konseling menjadi salah satu pilar dalam pendidikan di sekolah dalam upaya meningkatkan resiliensi dan kesejahteraan psikologis siswa (Suranata, 2015).

Kemampuan resiliensi yang dimiliki siswa berhubungan erat dengan pencapaian kesejahteraan psikologis (well-being) dan peningkatan kualitas kesehatan mental (Slade et al., 2017). Kaitan antara resiliensi dengan kesehatan mental dan kesejahteraan psikologis telah banyak dibahas dalam berbagai studi. Analisis longitudinal tentang hubungan antara resiliensi dengan kesehatan mental siswa yang dilakukan oleh Wu et al., (2020) menemukan bahwa resiliensi dapat secara signifikan memprediksi status kesehatan mental siswa. Dalam studi ini juga dipaparkan bahwa siswa yang memiliki resiliensi tinggi cenderung menunjukkan gangguan psikologis seperti depresi dan kecemasan yang lebih rendah dibandingkan siswa dengan tingkat resiliensi rendah. Resiliensi juga disebut sebagai salah satu faktor non-kognitif yang berkontribusi penting terhadap keberhasilan siswa dalam akademik serta perkembangan psikologis (Rosen et al., 2010).

Model konseling berbasis kekuatan (strength-based counseling) merupakan salah satu model konseling yang dapat digunakan dalam upaya meningkatkan resiliensi dan kesejahteraan psikologis siswa. Model ini berpedoman pada paradigma psikologi positif yang memandang bahwa setiap siswa memiliki potensi diri dan sumber daya yang penting untuk disadari dan dikembangkan (Scheel et al., 2018). Konsep-konsep dalam konseling berbasis kekuatan juga sejalan dengan paradigma baru penyelenggaraan layananan bimbingan dan konseling saat ini (comprehensive \& developmental counseling) yang memandang siswa sebagai individu yang memiliki sumber daya, potensi, serta kompetensi positif yang dapat diberdayakan untuk membantu siswa mencapai perkembangan diri secara optimal (Brewington \& Kushner, 2020; Gysbers, 2001; Lau \& Fung, 2008).

Meskipun merupakan model yang cenderung baru dalam praktik konseling, penggunaan model konseling berbasis kekuatan berpeluang untuk digunakan secara luas dalam pelayanan bimbingan dan konseling di sekolah sebagai upaya mengembangkan resiliensi, kesejahteraan psikologis, dan optimalisasi prestasi akademik (Waters, 2011). Beberapa studi telah melaporkan keefektifan model konseling berbasis kekuatan (Austin, 2005; Bernand \& Walton, 2011; Seligman et al., 2009). Di Indonesia khusunya, temuan menarik dari studi Suranata et al., (2017) menunjukkan bahwa konseling berbasis kekuatan memberikan dampak positif terhadap berkembangnya resiliensi siswa. Hasil studi tersebut juga telah membuktikan bahwa pengaruh konseling berbasis kekuatan dapat disejajarkan dengan model konseling mapan seperti CBT, REBT, SFBT serta model konseling lainnya (Suranata et al., 2017).

Dengan perkembangan teknologi informasi yang sangat signifikan, ditambah dengan situasi pandemi yang menuntut adaptasi teknologi dalam segala dimensi kehidupan, maka diperlukan pengembangan model konseling berbasis teknologi yang dapat mempermudah pelaksanaan layanan bimbingan dan konseling (Ifdil et al., 2020). Meskipun merupakan metode baru yang belum begitu optimal digunakan, pemanfataan teknologi dan informasi dalam layanan bimbingan dan konseling memiliki beberapa keuntungan yaitu dari segi waktu yang lebih efisien (Direktör, 2017; Hidayah, 2013; Suranata \& Prakoso, 2020). 
Penelitian ini bertujuan untuk menguji pengaruh model konseling berbasis kekuatan yang dikemas melalui platform LMS Schoology dalam meningkatkan kesehatan mental dan kesejahteraan psikologis siswa.

\section{Metode}

\section{Desain dan Prosedur Pengambilan Sampel Penelitian}

Penelitian ini menggunakan rancangan randomized control trial experiment (RCT). Rancangan RCT merupakan rancangan eksperimen yang prosfektif untuk mengukur efektivitas intervensi tertentu yang cenderung baru (L. Cohen et al., 2007). Rancangan RCT ini juga menekankan keketatan dalam memilih subjek penelitian, pengendalian terhadap intervensi yang akan dibandingkan (Sibbald \& Roland, 1998). Prosedur random control trial dalam penelitian ini adalah seperti ditampilkan pada gambar berikut.

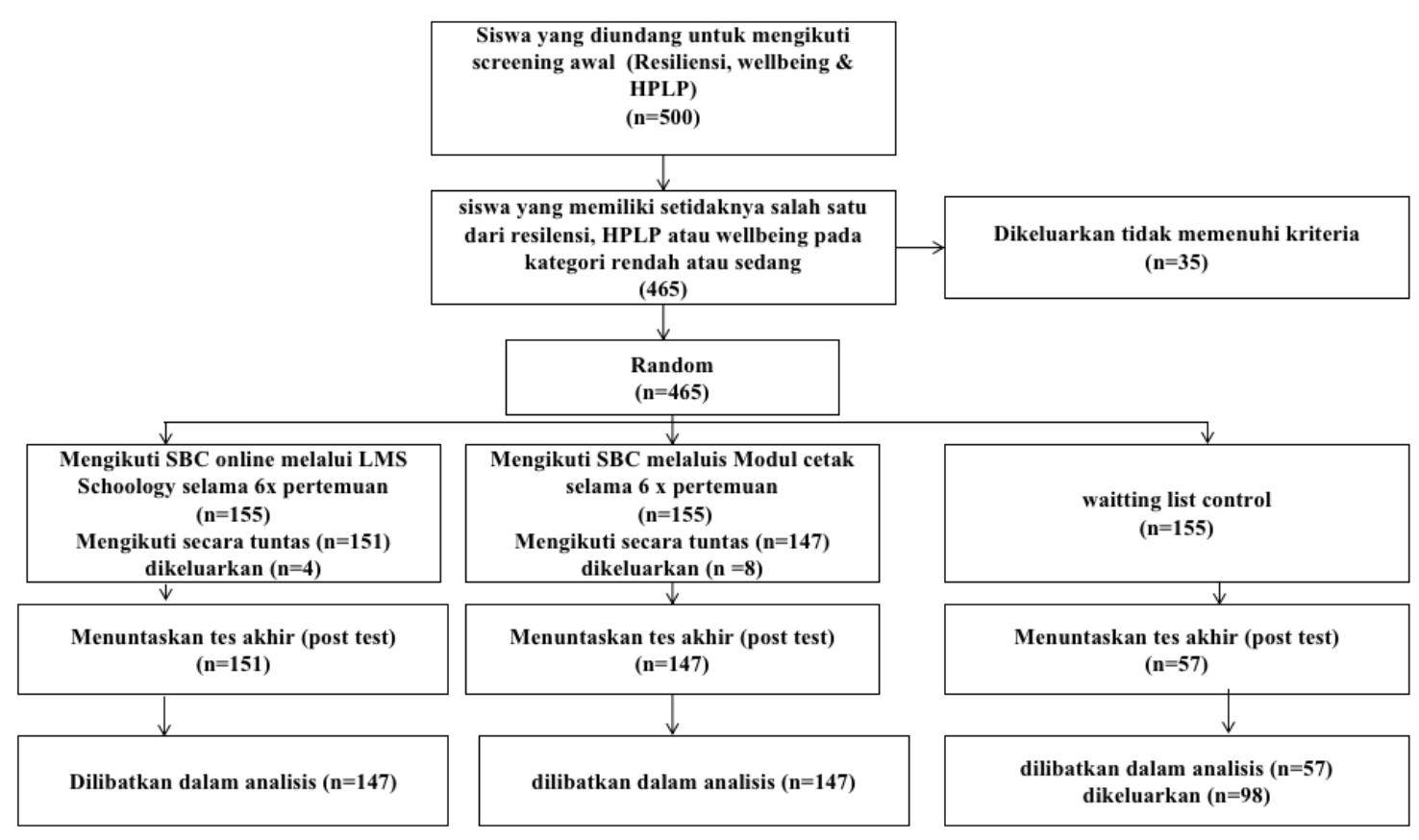

\section{Gambar 1. Prosedur Randomizeed Control Trial Experiment}

Berdasarkan gambar 01 di atas, prosedur eksperimen dalam rancangan RCT ini diawali dengan screening awal melalui skala resiliensi, HPLP dan well-being. Sebanyak 500 siswa dari 4 sekolah di wilayah Provinsi Bali diundang mengikuti screening awal ini. Screening awal dengan kriteria peserta berada pada kategori rendah palah satu hasil pengukuran yang digunakan yaitu resiliensi, HPLP dan well-being. Terdapat 465 siswa yang memenuhi kriteria yang ditentukan untuk ditempatkan secara acak (random assigment) ke dalam kelompokkelompok dengan masing-masing 155 siswa, yaitu pada kelompok pertama mengikuti konseling SBC online melalui LMS Schoology, kelompok kedua mengikuti konseling SBC melalui tutorial modul cetak, dan kelompok ketiga adalah kelompok waiting list control. Dari 155 siswa yang mengikuti intervensi SBC online melalui LMS Schoology sebanyak 151 siswa yang melaksanakan kegiatan sampai tuntas 6x pertemuan dan terdapat empat siswa yang tidak melaksanakan sampai tuntas. Pada kelompok kedua yang mengikuti SBC melalui modul cetak, sebanyak 147 siswa yang menyelesaikan semua pertemuan yang terdapat dalam modul (setara 6x pertemuan) dan 8 siswa tidak menuntaskan. Pada minggu ke 8 setelah kelompok pertama dan kedua menyelesikan program intervensi, terhadap peserta diadminsitrasikan post-test. Mortalitas terbanyak justru terjadi pada kelompok waiting list pada tahap post-test, hanya 57 siswa yang menyelesaikan semua jenis skala yang ditugaskan pada postest, sisannya sebanyak 98 siswa tidak menyelesaikan post-test dengan tuntas pada semua item skala.

\section{Instrumen Penelitian}

Terdapat tiga instrument pengukuran yang digunakan dalam penelitian ini, yaitu (1) skala well-being, (2) skala resiliensi, dan (3) HPLP. Pengukuran well-being menggunakan skala student's well-being menggunakan teori Ryff \& Keyes (1995). Skala well-being ini terdiri dari 96 item yang mengukur 6 dimensi yaitu self-acceptance, positive relations, autonomy, environmental mastery, purpose in life, dan personal growth. Setiap item pada skala ini memiliki valdiitas yang baik serta laporan validitas item dan reliabelitas skala pada Cronbach's Alpha sebesar 0.95 
(sangat tinggi). Laporan hasil pengujian skala ini dapat dilihat pada https://osf.io/yt2hg (Suranata, 2021b). Skala resiliensi yang digunakan adalah 14 item Indonesian version Psychological Resilience Youth Developement Module yang telah dilaporkan memiliki validitas item yang baik dan reliabelitas pada Cronbach's Alpha sebesar 0.777 yang berarti reliablitas cukup tinggi (Suranata et al., 2017b). Instrumen skala Health- Promoting Lifestyle Profile Indonesia Version (HPLP II) dalam versi aslinya menggunakan Bahasa Inggris pertama kali dikembangkan oleh Walker, Sechrist, \& Pender (1995) yang mengukur lima dimensi gaya hidup dan kesehatan, yang meliputi: tanggung jawab terhadap kesehatan; aktifitas fisik; nutrisi, perngembangan spiritual; hubungan interpersonal; dan pengelolaan stres. Versi Indonesia skala ini terdiri dari 52 item, yang pada setiap item responden memilih satu dari empat pilihan tanggapan, yaitu: selalu (skor 4); sering (3); kadang-kadang (2) dan tidak pernah (1). Skala HPLP dalam studi ini telah diterjemahkan ke dalam Bahasa Indonesia melalui pakar penerjemahan Bahasa Inggris-Indonesia dan melalui pengujian validitas dan reliabelitas pada populasi siswa SMA di Indonesia. Hasil uji validitas menunjukkan semua item HPLP versi Indonesia memiliki nilai validasi item yang baik dengan tingkat reliabelitas Alpha Cronbach 0,95 (sangat baik). Laporan hasil pengujian reliabelitas skala ini dapat di lihat pada https://osf.io/v2en3/ (Suranata, 2021a).

\section{Prosedur Strength-based Counseling Online melalui LMS Schoology}

Konseling strength-based online (SBC) melalui LMS Schoology dilaksanakan dengan beberapa prosedur meliputi (1) siswa melakukan registrasi akun untuk dapat bergabung dalam modul SBC, (2) setelah bergabung, siswa dapat mengkases kegiatan-kegiatan konseling dalam LMS yang memadukan antara synchronous melalui tatap maya/video conference dan unsynchronous melalui video tutorial dan form latihan. Terdapat empat tahapan/teknik SBC yang diikuti oleh siswa, yaitu (1) tahap menarasikan diri melalui teknik naratif, (2) tahap menemukan kekuatan dalam diri, (3) tahap menumbuhkan harapan dan menemukan solusi, dan (4) tahap menemukan makna diri melalui teknik forgiveness dan lingkaran pengampunan. Setiap tahapan dan teknik SBC dalam LMS Schoology disertai dengan tutorial video implementasi teknik, form latihan implementasi teknik oleh siswa, dan forum diskusi melalui video conference ataupun forum diskusi tidak tersinkronisasi di LMS. Tampilan dari LMS Schoology SBC seperti gambar berikut.

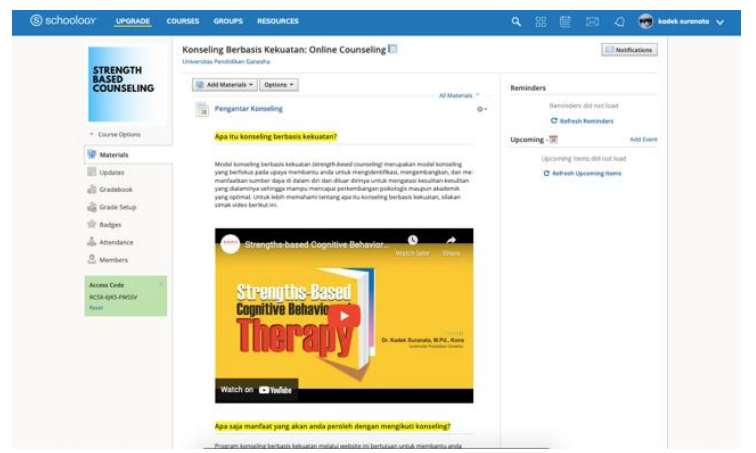

Gambar 02. Tampilan dashboard SBC online dalam LMS Schoology

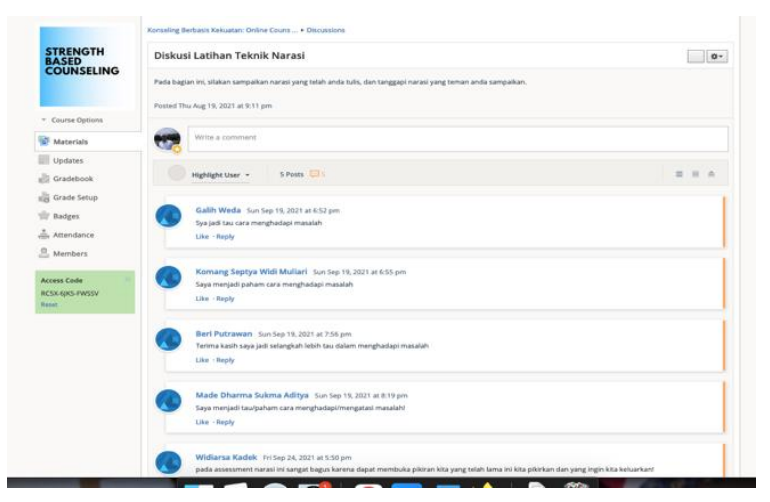

Gambar 04. Tampilan aktivitas diskusi siswa secara unsynchronous

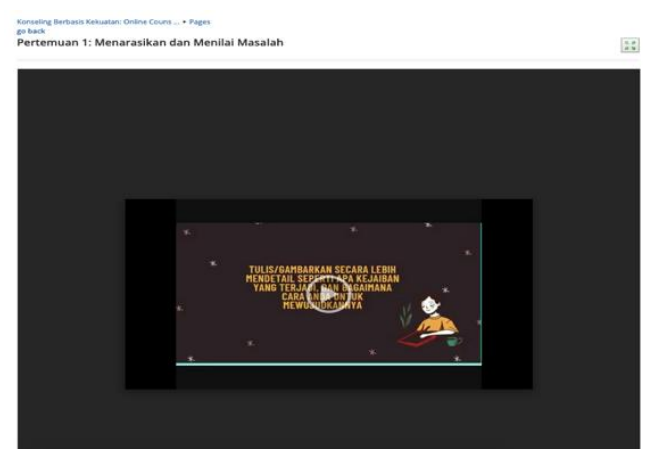

Gambar 03. Tampilan menu tutorial melalui video

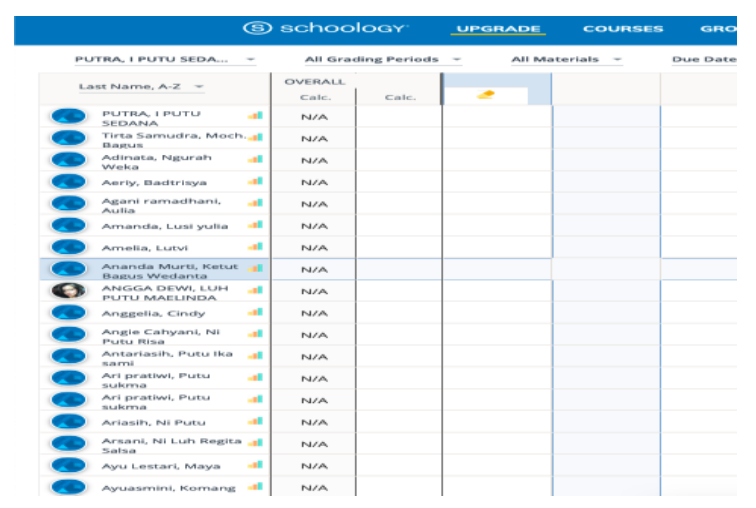

Gambar 05. Tampilan rekap dan laporan aktivitas siswa mengikuti konseling 


\section{Prosedur Strength-based Counseling melalui Modul Cetak}

Konseling strength-based (SBC) melalui modul cetak merupakan kegiatan mandiri (self-help). Peserta kegiatan diberikan modul SBC, kemudian mengisi capaian konselingnya pada lembar kerja yang telah disediakan pada modul. Tahapan dan teknik pada modul cetak ini sama dengan isi tahapan dan teknik SBC online dalam LMS Schoology. Pelaksanaan kegiatan difasilitasi oleh konselor melalui WhatsApp group. Setiap siswa melaporkan capaian konseling dalam lembar kerja siswa kepada konselor setiap minggu. Pada akhir sesi, siswa mengumpulkan kembali modul SBC yang telah selesai dilaksanakan. Fasilitator kemudian melakukan evaluasi terhadap proses dan hasil implementasi tahapan dan teknik konseling yang telah dilaksanakan siswa.

\section{Prosedur Analisis Data}

Program statistik JASP versi 0.13 for Mac digunakan dalam analisis data terkait penyajian data deskriptif, analisis MANOVA dan juga ANOVA (JASP Team, 2021). Untuk meminimalkan bias pengaruh intervensi terhadap variabel terikat yang diuji dalam penelitian ini yang diakibatkan ketidaksamaan kondisi awal antar kelompok, data yang diuji dalam statistik MANOVA dan ANOVA adalah data gain score. Adapun formulasi untk menghitung gain score adalah sebagai berikut.

$$
g=\frac{\text { (postest score }- \text { pretest score }}{\text { max score }- \text { pretest score }}
$$

(adaptasi dari Cohen, 1988)

Analisis statistik MANOVA dilakukan untuk menguji perbedaan tiga variabel terkait yaitu resiliensi, wellbeing, dan HPLP secara simultan pada tiga kelompok. Sementara analisis statistik ANOVA satu jalur digunakan untuk menguji perbedaan setiap variabel secara terpisah pada tiga kelompok responden. Prosedur uji asumsi statistik parametrik untuk MANOVA dan ANOVA telah dilakukan sebelum semua analisis dilakukan. Dataset dan hasil analisis statistik deskriptif untuk uji MANOVA dan ANOVA pada penelitian ini dapat diakses pada https://osf.io/wgfdz (Suranata, 2021c).

\section{Hasil dan Pembahasan}

Deskripsi data yang menampilkan kondisi pada tes awal (pre-test) dan tes akhir (post-test) pada variabel wellbeing, resiliensi, dan HPLP pada kelompok eksperimen 1 dan 2 serta kelompok control waiting list disajikan pada tabel dan gambar berikut.

Tabel 1. Deskripsi Data Pretest-Postest-Gain Score Well-being, Resiliensi, dan HPLP pada Kelompok Eksperimen dan Waiting Control List

\begin{tabular}{|c|c|c|c|c|c|c|c|c|c|}
\hline & \multicolumn{3}{|c|}{ Wellbeing } & \multicolumn{3}{|c|}{ Resilience } & \multicolumn{3}{|c|}{ HPLP } \\
\hline & pretest & $\begin{array}{c}\text { M(sd) } \\
\text { posttest }\end{array}$ & Gains & est & $\begin{array}{c}M(s d) \\
\text { posttest }\end{array}$ & Gains & retest & $\begin{array}{c}\text { M(sd) } \\
\text { posttest }\end{array}$ & Gains \\
\hline $\begin{array}{c}\text { Eksp 1 } \\
(\mathrm{n}=151)\end{array}$ & & & 1.45 & & & 1.88 & & $\begin{array}{l}154.296 \\
(30.013)\end{array}$ & $\begin{array}{c}1.70 \\
(1.39)\end{array}$ \\
\hline $\begin{array}{c}\text { Eksp 2 } \\
(\mathrm{n}=148)\end{array}$ & 310.2 & 315.67 & 0.1 & 31 & 33.740 & 0.4 & 114 & 116 & $\begin{array}{c}0.09 \\
0.64)\end{array}$ \\
\hline $\begin{array}{l}(\mathrm{n}=148) \\
\text { Waitlist }\end{array}$ & 310.628 & 311 & 0.0 & 33.628 & 29. & -0 & 114 & 115.302 & 0.04 \\
\hline$(\mathrm{n}=$ & 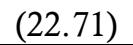 & (28.37) & & 5 & & & & $(8.776$ & $(0$. \\
\hline
\end{tabular}

Pada tabel 1, rata-rata skor well-being pada kelompok eksperimen I (SBC online melalui LMS Schoology) mengalami peningkatan dari pre-test sebesar 291.94 (31.80) menjadi 334.73 (31.82) pada post-test. Pada kelompok eksperimen II (SBC melalui modul cetak) juga mengalami peningkatan skor rata-rata well-being dari pre-test sebesar 310 (24.98) menjadi 315.73 (31.82) pada post-test. Sedangkan pada kelompok waiting list, rata-rata skor pre-test sebesar 310.628 (22.71) menjadi 311.61 (28.37) pada post-test. Pada variabel resiliensi, rata-rata skor kelompok eksperimen I mengalami peningkatan dari pre-test 31.308 (4.865) menjadi 44.170 (6.649) pada post-test. Rata-rata skor pada kelompok eksperimen II juga mengalami peningkatan dari pre-test 31.416 (4.958) menjadi 33.740 (6.195) pada post-test. Sedangkan pada kelompok waiting-list, rata-rata skor pretest sebesar 33.628 (5.127) menjadi 29.884 (3.354) pada post-test. Pada variabel HPLP, rata-rata skor kelompok eksperimen I mengalami peningkatan dari pre-test sebesar 114.516 (9.732) menjadi 154.296 (30.013) pada post-test. Peningkatan rata-rata skor juga dialami oleh kelompok eksperimen II yakni 114.039 (7.970) pada pre-test menjadi 116.344 (11.988) pada post-test. Pada kelompok waiting-list skor rata-rata pre-test sebesar 114.32 (9.65) menjadi 115.302 (8.776) pada post-test. 

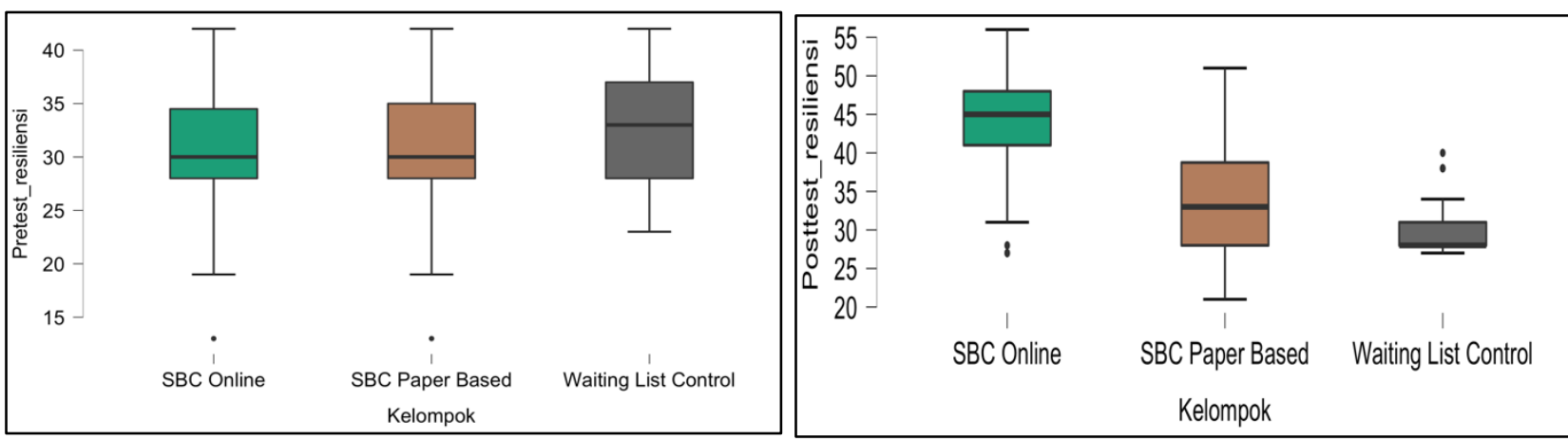

Gambar 6. Boxplot pretest-postest resiliensi pada kelompok eksperimen I, eksperimen II dan waiting list control
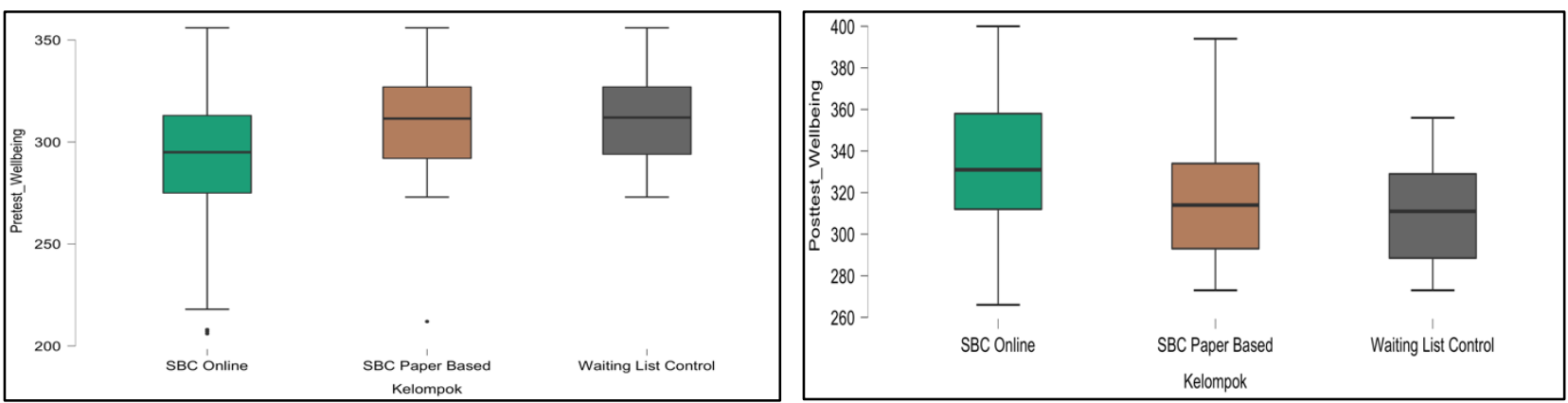

Gambar 7. Boxplot pretest-posttest well-being pada kelompok eksperimen I, eksperimen II, dan waiting list control
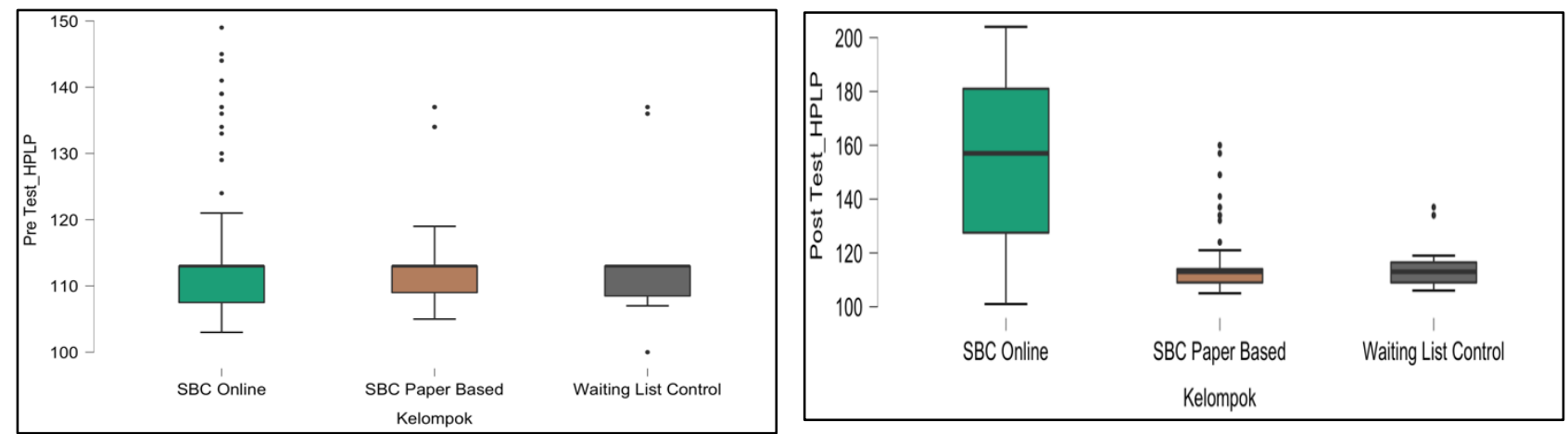

Gambar 8. Boxplot pretest-postest HPLP pada kelompok eksperimen I, eksperimen II, dan waiting list control

Pada gambar diatas, dapat diketahui bahwa kelompok eksperimen I merupakan kelompok yang menunjukkan peningkatan skor pre-test ke post-test paling nyata pada setiap variabel amatan. Pada amatan awal (pre-test), kelompok eksperimen I tidak menunjukkan perbedaan yang nyata pada semua variabel dengan kelompok lainnya. Namun pada amatan akhir (post-test), kelompok eksperimen I secara nyata menunjukkan skor lebih tinggi pada semua variabel dibandingkan kelompok lainnya. Untuk mengetahui apakah perbedaan tersebut cukup memiliki arti atau signifikan, maka dilakukan analisis MANOVA dan ANOVA.

Hasil uji MANOVA pada pada Pillai's trace, Wilks's lambda, Hotelling-Lawley trace dan Roy's Largest root (dapat dilihat pada https://osf.io/wgfdz) semua signifikan $(p<.001)$ yang dapat dimaknai bahwa perbedaan jenis intervensi (SBC online melalui LMS Schoology dengan modul cetak) berpengaruh terhadap perbedaan well-being, resiliensi, dan HPLP secara bersama-sama. Selanjutnya analisis varians dilakukan untuk mengetahui pengaruh setiap perlakuan terhadap masing-masing variabel terikat tersebut. 
Tabel 2. Analisis ANAVA Well-being, Resiliensi, dan HPLP antar Kelompok Eksperimen I, II, dan Waiting List Control

\begin{tabular}{lrrcccc}
\hline \multicolumn{1}{c}{ Cases } & Sum of Squares & \multicolumn{1}{c}{ df } & Mean Square & $\mathbf{F}$ & $\mathbf{p}$ & $\boldsymbol{\eta}^{2} \mathbf{p}$ \\
\hline Wellbeing & & & & & & \\
Kelompok & 149.267 & 2 & 74.633 & 51.461 & $<.001$ & 0.226 \\
$\begin{array}{l}\text { Residuals } \\
\text { Resilience }\end{array}$ & 511.950 & 353 & 1.450 & & & \\
Kelompok & 303.575 & 2 & 151.788 & 97.282 & $<.001$ & 0.355 \\
$\begin{array}{l}\text { Residuals } \\
\text { HPLP }\end{array}$ & 550.782 & 353 & 1.560 & & & \\
Kelompok & 230.107 & 2 & 115.053 & 106.433 & $<.001$ & 0.376 \\
Residuals & 381.590 & 353 & 1.081 & & & \\
\hline
\end{tabular}

Note. Type III Sum of Squares

Hasil analisis Anava menunjukkan perbedaan yang signifikan pada semua variabel. Pada variable well-being nilai $\mathrm{F}(2,353)=51.461, \mathrm{p}<0.001$, pada variabel resiliensi nilai $\mathrm{F}(2,353)=106.433, \mathrm{p}<.001$, dan pada variabel HPLP nilai $\mathrm{F}(2,353)=106.433, \mathrm{p}<.001$. Nilai efek size $\boldsymbol{\eta}_{\mathrm{p}}^{2}$ yang cukup tinggi ditunjukkan pada semua variabel yang diuji.

Tabel 3. Post-Hoc Comparasion Tukey Well-being, Resiliensi, HPLP antar Kelompok Eksperimen I, II, dan Waiting List Control

\begin{tabular}{llcrrr}
\hline & Mean Difference & SE & t & $\mathbf{p}_{\text {tukey }}$ \\
\hline Resilience & & & & & \\
SBC, Online & SBC, Paper, Based & 1.454 & 0.141 & 10.294 & $<.001$ \\
& Waiting, List, Control & 2.627 & 0.215 & 12.237 & $<.001$ \\
SBC, Paper, Based & Waiting, List, Control & 1.174 & 0.215 & 5.448 & $<.001$ \\
Wellbeing & & & & \\
SBC, Online & SBC, Paper, Based & 1.266 & 0.136 & 9.299 & $<.001$ \\
& Waiting, List, Control & 1.417 & 0.207 & 6.847 & $<.001$ \\
SBC, Paper, Based & Waiting, List, Control & 0.151 & 0.208 & 0.727 & 0.747 \\
HPLP & & & & & \\
SBC, Online & SBC, Paper, Based & 1.604 & 0.118 & 13.648 & $<.001$ \\
& Waiting, List, Control & 1.661 & 0.179 & 9.296 & $<.001$ \\
SBC, Paper, Based & Waiting, List, Control & 0.057 & 0.179 & 0.317 & 0.946 \\
\hline
\end{tabular}

Note. P-value adjusted for comparing a family of 3

Analisis lanjutan (Post-Hoc) dengan test Tukey pada tabel 3 juga menunjukkan bahwa terdapat perbedaan yang sugnifikan antar ketiga kelompok. Kelompok yang mengikuti SBC online melalui LMS Schoology memiliki well-being, resiliensi, dan HPLP yang lebih tinggi secara signifikan dibandingkan dengan kelompok lainnya. Sementara kelompok partisipan yang mengikuti SBC melalui modul cetak diketahui memiliki resiliensi yang lebih tinggi secara signifikan dibandingkan dengan kelompok waiting list control. Namun tidak pada variabel well-being dan HPLP. Hasil analisis ini menunjukkan bahwa konseling strength-based (SBC) online melalui LMS Schoology berpengaruh secara efektif terhadap peningkatan well-being, resiliensi, dan gaya hidup siswa. Sementara SBC yang dilakukan melalui panduan modul cetak hanya efektif untuk peningkatan resiliensi siswa.

Hasil penelitian ini menunjukkan bukti bahwa konseling strength-based (SBC) dengan metode online yang dilakukan melalui LMS Schoology merupakan intervensi yang efektif untuk membantu siswa meningkatkan gaya hidup dan perilaku hidup sehat, resiliensi, dan kebahagiaan (well-being). Metode intervensi ini lebih efektif dibandingkan dengan pelaksanaan konseling mandiri (self-help) berbantuan modul cetak yang hanya efektif untuk meningkatkan resiliensi. Hasil penelitian ini mendukung bukti emperik bahwa konseling online dengan media website merupakan metode intervensi yang efektif untuk kalangan siswa (Ardi \& Ifdil, 2013; Haryati, 2020; Hastuti \& Tyas, 2021; Suranata \& Prakoso, 2020). Hasil penelitian ini juga mendukung bukti emperik tentang kemanjuran model konseling berbasis kekuatan (strength-based counseling) yang sebelumnya juga telah dicatat dalam penelitian Suranata et al.(2017a) dan Suranata (2019). 
Hasil penelitian ini memberikan sumbangan yang positif secara teoretis dan praktis terhadap pelayanan bombing dan dan konseling di sekolah. Model intervensi SBC online melalui media LMS ini dapat dipertimbangkan menjadi solusi terhadap permasalahan yang dialami para konselor sekolah dalam menyediakan intervensi yang efektif sesuai dengan kondisi pembatasan kegiatan masyarakat dalam pencegahan peyebaran wabah COVID-19.

\section{Simpulan}

Berdasarkan hasil penelitian ini, dilaporkan terdapat perbedaan well-being, resiliensi, dan HPLP yang signifikan antara siswa yang mengikuti konseling berbasis kekuatan (SBC) online melalui LMS Schoology dengan siswa yang mengikuti metode konseling mandiri (self-help) dengan panduan modul cetak. Hasil tersebut menunjukkan bahwa SBC dengan metode online yang dilakukan melalui media LMS Schoology merupakan metode intervensi yang efektif untuk membantu siswa meningkatkan gaya hidup dan perilaku sehat, meningkatkan resiliensi, serta kesejahteraannya (well-being). Temuan-temuan dalam penelitian ini berimplikasi terhadap praktik layanan bimbingan dan konseling di sekolah dalam upaya meningkatkan kesehatan mental dan kesejahteraan psikologis siswa. Berdasarkan hasil penelitian ini, direkomendasikan kepada guru $\mathrm{BK} /$ konselor sekolah agar dapat mengadaptasi penggunaan teknologi informasi guna mendukung keefektifan layanan bimbingan dan konseling.

\section{Ucapan Terima Kasih}

Penelitian ini dibiayai dari dana DIPA Universitas Pendidikan Ganesha melalui Hibah Penelitian LP2M Universitas Pendidikan Ganesha tahun 2021. Ucapan terimakasih juga disampaikan kepada mahasiswa tim pengumpul data, kepala sekolah mitra, para guru BK, serta siswa-siswi yang dilibatkan dalam penelitian ini.

\section{Referensi}

Ardan, M., Rahman, F. F., \& Geroda, G. B. (2020). The influence of physical distance to student anxiety on COVID-19, Indonesia. Journal of Critical Reviews, 7(17), 1126-1132. https://doi.org/10.31838/jcr.07.17.141

Ardi, Z., \& Ifdil, I. (2013). Konseling Online Sebagai Salah Satu Bentuk Pelayanan E-konseling. Jurnal Konseling Dan Pendidikan, 1(1), 15-22.

Austin, D. (2005). The effects of a strengths development intervention program upon the self-perception of students' academic abilities. Dissertation Abstracts International, 66.

Bernand, M., \& Walton, K. (2011). The effect of You Can Do It! Education in six schools on student perceptions of wellbeing, teaching, learning and relationships. Journal of Student Wellbeing, 5, 22-37.

Brewington, M., \& Kushner, J. (2020). School Counselor Perceptions of a Comprehensive School Counseling Model and Implications for Practice. Administrative Issues Journal, 10(2).

Cohen, J. (1988). Set correlation and contigency tables. Applied Psychological Measurement, 12(4), 425-434.

Cohen, L., Manion, L., \& Morrison, K. (2007). Research Methods in Education. In Professional Development in Education (Sixth, Vol. 38, Issue 3). Routledge. https://doi.org/10.1080/19415257.2011.643130

Cornine, A. (2020). Reducing Nursing Student Anxiety in the Clinical Setting: An Integrative Review. Nursing Education Perspectives, 41(4), 229-234. https://doi.org/10.1097/01.NEP.0000000000000633

Direktör, C. (2017). A new area of mental health care: online therapy, counseling and guidance. Journal of Research in Humanities and Social Science, 5(2), 78-83.

Gysbers, N. . (2001). School guidance and counseling in the 21st century: Remember the past into the future. Professional School Counseling, 5(2), 96-105.

Haryati, A. (2020). Online Counseling Sebagai Alternatif Strategi Konselor dalam Melaksanakan Pelayanan E-Counseling di Era Industri 4.0. Bulletin of Counseling and Psychotherapy, 2(2), 27-38. https://doi.org/10.51214/bocp.v2i2.33

Hastuti, M. M. S., \& Tyas, P. H. P. (2021). Online Media Usage in Guidance and Counseling Services during Covid-19 Pandemic. Jurnal Kajian Bimbingan Dan Konseling, 6(2), 60-70. https://doi.org/10.17977/um001v6i22021p060-070

Hidayah, N. (2013). Online cognitive behavioral counseling model to improve junior high school students' self-regulated learning. The International Conference. http://repository.uniska-bjm.ac.id/398/1/Artikel ICCE .pdf\#page $=58$

JASP Team. (2021). JASP (0.13).

Lau, P. S. ., \& Fung, S. . (2008). School Guidance and Counseling in an International Context : A Reaction 
Paper. Assian Journal of Counselling, 15(2), 207-228.

Lee, J. (2020). Mental health effects of school closures during COVID-19. The Lancet Child and Adolescent Health, 4(6), 421. https://doi.org/10.1016/S2352-4642(20)30109-7

Li, S., Wang, Y., Xue, J., Zhao, N., \& Zhu, T. (2020). The impact of covid-19 epidemic declaration on psychological consequences: A study on active weibo users. Int J Environ Res Public Health [revista en Internet] 2020 [acceso 13 de abril de 202021]; 30(3): 201-205. International Journal of Environmental Research and Public Health, 17(6). https://www.ncbi.nlm.nih.gov/pmc/articles/PMC7143846/pdf/ijerph17-02032.pdf

Oktawirawan, D. H. (2020). Faktor Pemicu Kecemasan Siswa dalam Melakukan Pembelajaran Daring di Masa Pandemi Covid-19. Jurnal Ilmiah Universitas Batanghari Jambi, $20(2), 541$. https://doi.org/10.33087/jiubj.v20i2.932

Puteh, M., \& Khalin, S. . (2016). Mathematics Anxiety and Its Relationship with the Achievement of Secondary Students in Malaysia. International Journal of Social Science and Humanity, 6(2), 119-122. https://doi.org/10.7763/ijssh.2016.v6.630

Rinawati, D., \& Darisman, E. K. (2020). Survei tingkat kejenuhan siswa SMK belajar di rumah pada mata pelajaran produk kreatif dan kewirausahaan selama masa pandemi covid-19. Journal of Science and Education (JSE), 1(1), 32-40.

Rosen, J. ., Glennie, E. ., Dalton, B. ., Lennon, J. ., \& Bozick, R. . (2010). Non-cognitive skills in the classroom: New perspectives on educational research. Research Triangle Institute Press.

Ryff, C. D., \& Keyes, C. L. M. (1995). The structure of psychological well-being revisited. Journal of Personality and Social Psychology, 69(4), 719-727. https://doi.org/10.1037/0022-3514.69.4.719

Scheel, M. ., Stabb, S. ., Cohn, T. ., Duan, C., \& Sauer, E. . (2018). Counseling psychology model training program. The Counseling Psychologist, 46(1), 6-49.

Seligman, M. E. P., Ernest, R., Gillham, J., Reivich, K., \& Linkin, M. (2009). Positive education: Positive psychology and classroom interventions. Oxford Review of Education, 35, 293-311.

Sibbald, B., \& Roland, M. (1998). Understanding controlled trials. Why are randomized controlled trials important? BMJ:British Medical Journal, 316(7126).

Singh, S., Roy, D., Sinha, K., Parveen, S., Sharma, G., \& Joshi, G. (2020). Impact of COVID-19 and lockdown on mental health of children and adolescents: A narrative review with recommendations. Psychiatry Research, 293(August), 113429. https://doi.org/10.1016/j.psychres.2020.113429

Slade, M., Oades, L., \& Jarden, A. (2017). Wellbeing, Recovery and Mental Health. Cambridge University Press. https://doi.org/https://doi.org/10.1017/9781316339275

Suranata, K. (2019). The pilot study of SMART-Resilience a psycho-educational program. COUNS-EDU: The International Journal of Counseling and Education, 4(3), 121. https://doi.org/10.23916/0020190424230

Suranata, K. (2021a). Indonesian Version HPLP Reliability Rapport. osf.io/v2en3

Suranata, K. (2021b). Indonesian Well-being Scale Reliability Report. https://doi.org/10.17605/OSF.IO/YT2HG

Suranata, K. (2021c). Manova and Anova Results Resilience, Wellbeing, HPLP among Group in RCT of SBC Online. https://doi.org/10.17605/OSF.IO/WGFDZ

Suranata, K. (2015). Caring Community As a strengthened in the Education Efforts to promote Student Resilience. Proceedings of Scientific Forum-Faculty of Education Department Of Science Education (FIP-JIP) and International Seminar, 290-300.

Suranata, K., Atmoko, A., \& Hidayah, N. (2017a). Enhancing Students' Resilience: Comparing The Effect of Cognitive-Behavior And Strengths-Based Counseling. 134(Icirad), 102-108. https://doi.org/10.2991/icirad17.2017.20

Suranata, K., Atmoko, A., \& Hidayah, N. (2017b). Validation of Psychological Resilience Youth Developement Module and Implication for Guidance and Counseling. GUIDENA: Jurnal Ilmu Pendidikan, Psikologi, Bimbingan Dan Konseling, 7(1), 57. https://doi.org/10.24127/gdn.v7i1.648

Suranata, K., \& Prakoso, B. B. (2020). Program web-based SFBC untuk mereduksi kecemasan akademik siswa saat pandemi COVID-19; sebuah pilot studi. JPPI (Jurnal Penelitian Pendidikan Indonesia), 6(2), 4752. https://doi.org/10.29210/02020609

Thahir, A. I. A., Iqbal, M., Maharani, S. A., \& Syam, A. (2020). The emotional state and physical condition of indonesian college students: An emerging situation during the coronavirus disease-19 crisis in Indonesia. Open Access Macedonian Journal of Medical Sciences, 8(T1), 261-267. https://doi.org/10.3889/oamjms.2020.5283

Wahid, S. N. S., Yusof, Y., \& Nor, A. H. M. (2018). Effect of mathematics anxiety on students' performance in higher education level: A comparative study on gender. AIP Conference Proceedings, 1974. https://doi.org/10.1063/1.5041710

Waters, L. (2011). A Review of School-Based Positive Psychology Interventions. The Australian Educational and Developmental Psychologist, 28(2), 75-90. https://doi.org/https://doi.org/10.1375/aedp.28.2.75 
Wu, Y., Sang, Z. Q., Zhang, X. C., \& Margraf, J. (2020). The Relationship Between Resilience and Mental Health in Chinese College Students: A Longitudinal Cross-Lagged Analysis. Frontiers in Psychology, 11(February). https://doi.org/10.3389/fpsyg.2020.00108 